\title{
PENGARUH PENGAWASAN TERHADAP KEPATUHAN PENGGUNAAN ALAT PELINDUNG DIRI DI PT JAMU AIR MANCUR PALUR
}

\section{Effect of Supervision on Compliance Use of Personal Protective Equipment in PT Jamu Air Mancur Palur}

\author{
Yusuf Bachtiyar Lobis ${ }^{1)}$, Dwi Ariyanto ${ }^{2)}$, Warsini ${ }^{3)}$ \\ ${ }^{1}$ S2 Ilmu Kesehatan Masyarakat, Pascasarjana, Universitas Sebelas Maret, Jl. Ir. Sutami 36 A, Kentingan \\ Surakarta 57126 telp. (0271) 662622 \\ ${ }^{2)}$ Universitas Veteran Bangun Nusantara Sukoharjo, Jalan Sujono Sukoharjo \\ E-mail: bachtiyar03@gmail.com
}

\begin{abstract}
ABSTRAK
Latar Belakang: Proses pengawasan sangat dibutuhkan untuk meningkatkan perilaku kepatuhan terhadap penggunaan alat pelindung diri oleh pekerja di tempat kerja. Tujuan penelitian ini adalah mengetahui pengaruh pengawasan terhadap kepatuhan penggunaan alat pelindung diri di PT Jamu Air Mancur Palur.

Metode: Desain penelitian ini adalah cross sectional. Populasi adalah seluruh pekerja PT Jamu Air Mancur Palur sebanyak 345 orang. Sampel kasus 78 orang. Analisis data menggunakan uji paired sample $\mathrm{t}$ test dengan taraf signifikan $95 \%$.

Hasil: Hasil penelitian menunjukkan adanya pengaruh antara pengawasan terhadap kepatuhan penggunaan APD di PT JAM Palur dengan nilai signifikansi sebesar 0,000 < 0,05 .

Kesimpulan: Ada pengaruh antara pengawasan terhadap kepatuhan penggunaan APD di PT JAM Palur. Pihak PT JAM Palur diharapkan bisa meningkatkan, memperketat dan menyiapkan petugas khusus pengawasan penggunaan APD pada pekerja.
\end{abstract}

Kata kunci: Pengawasan, kepatuhan dan alat pelindung diri 


\section{ABSTRACT}

Background: Supervision processes are urgently needed to improve compliance behavior with the use of personal protective equipment by workers in the workplace. The purpose of this study was to determine the effect of supervision on compliance with the use of personal protective equipment at PT Jamu Air Mancur Palur.

Method: The design of this study was cross sectional. The population is all 345 PT Jamu Air Mancur Palur workers. Case sample of 78 people. Data analysis used paired sample $t$ test with a significance level of $95 \%$.

Results: The results showed an influence between supervision of compliance with PPE use at PT JAM Palur with a significance value of $0,000<0.05$.

Conclusion: there is an influence between supervision of compliance with PPE use at PT JAM Palur. PT JAM Palur is expected to improve, tighten and prepare special officers to supervise the use of PPE for workers.

Keywords: Supervision, compliance and personal protective equipment

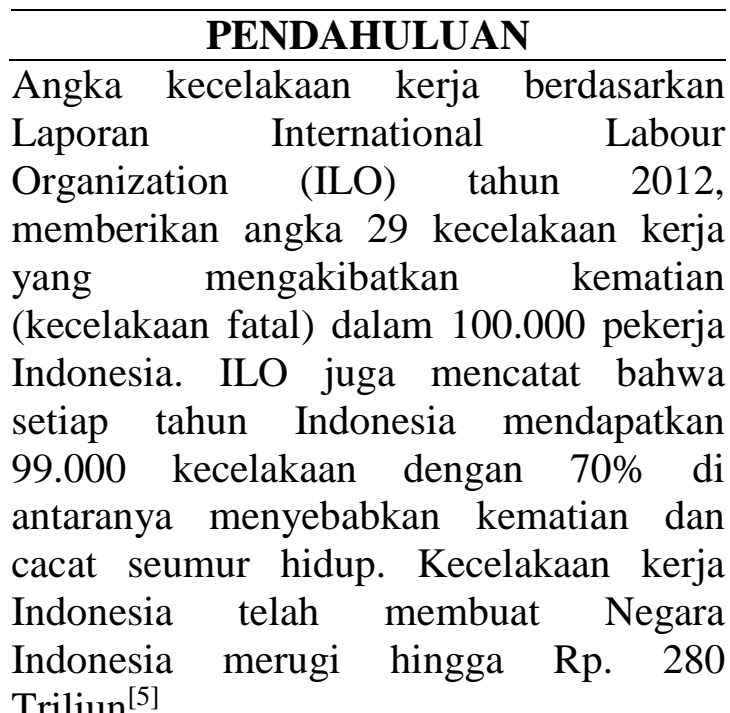

Triliun $^{[5]}$.

Alat Pelindung Diri (APD)

merupakan seperangkat alat yang digunakan oleh tenaga kerja untuk melindungi seluruh atau sebagian tubuhnya terhadap kemungkinan adanya potensi bahaya kecelakaan kerja pada tempat kerja ${ }^{[9]}$. Jika APD sudah digunakan secara baik dan benar, maka kecelakaan kerja dapat dikurangi dan keselamatan pekerja dapat meningkat. Keselamatan pekerja merupakan faktor yang sangat dominan dalam suatu industri, karena majunya suatu industri sangatlah dipengaruhi pula adanya suatu jaminan keselamatan para pekerjanya. Jadi hal tersebut merupakan kunci akan lancarnya suatu produktifitas dari suatu perusahaan ${ }^{[9]}$.

Ketidakpatuhan pengunaan APD sangat mempengaruhi kejadian kecelakaan akibat kerja dan penyakit akibat kerja yang akan menyebabkan 5 jenis kerugian diantaranya adalah kerusakan, kekacauan organisasi, keluhan dan kesedihan, kelainan, cacat serta kematian $^{[8]}$.

Penelitian Wibowo (2010) faktor yang berpengaruh terhadap kepatuhan penggunaan APD salah satunya adalah pengawasan. Penelitian terdahulu oleh Bustanul Arifin tahun 2013 menyatakan bahwa sebanyak 53,1 \% pengawasan terhadap kepatuhan penggunaan APD tergolong tidak baik. Adapun hasil uji chisquare didapat p-value sebesar 0,002 sehingga terdapat hubungan antara pengawasan pekerja operator dengan kepatuhan penggunaan APD.

Perusahaan yang ingin meningkatkan penggunaan APD harus benar-benar memperhatikan pengawasan terhadap pekerja. Hal tersebut sama halnya seperti PT Jamu Air Mancur Palur yang merupakan salah satu perusahaan yang bergerak di bidang pembuatan jamu. PT Jamu Air Mancur telah menyediakan APD secara cuma-cuma kepada tenaga kerjanya. Secara keseluruhan APD yang 
disediakan oleh PT Jamu Air Mancur telah sesuai dengan jumlah tenaga kerja dan disesuaikan dengan kebutuhan tenaga kerja di masing-masing bagian di proses produksi.

PT Jamu Air Mancur mewajibkan tenaga kerjanya menggunakan APD selama bekerja di proses produksi. Beberapa tenaga kerja masih ada yang tidak patuh menggunaan APD di PT Jamu Air Mancur. Hasil studi pendahuluan menyatakan bahwa kepatuhan penggunaan APD oleh tenaga kerja dilaksanakan dengan baik jika diawasi oleh petugas HRD, padahal pemantauan tidak terus menerus dilakukan dan hanya dilakukan dua minggu sekali bahkan satu bulan sekali.

Berdasarkan uraian diatas, maka penulis tertarik mengambil judul penelitian tentang "Pengaruh Pengawasan terhadap Kepatuhan Penggunaan Alat Pelindung Diri di PT Jamu Air Mancur Palur".

\section{METODE PENELITIAN}

Jenis penelitian ini adalah penelitain Observasional dengan pendekatan cross sectional. Variabel independent adalah pengawasan sedangkan Variabel dependen.adalah kepatuhan penggunaan alat pelindung diri. Populasi dalam penelitian ini adalah semua pekerja PT Jamu Air Mancur Palur yang berjumlah 345 orang pekerja. Teknik pengambilan sampel adalah purposive sampling. Lokasi penelitian di PT Jamu Air Mancur Palur dilaksanakan bulan Mei 2015. Data yang digunakan adalah data primer yang diperoleh melalui observasi dan wawancara sedangkan data sekunder diperoleh dari PT. JAM Palur dan bukubuku referensi lainnya. Analisis data dengan analisis univariat untuk melihat distribusi dan frekuensi variabel dependent serta dependent dan analisis bivariat untuk mengetahui hubungan antara variabel pengetahuan dan perilaku dengan kepatuhan penggunaan APD yang dianalisis dengan uji paired sample t test dengan nilai $\alpha=5 \%=0,05$ pada taraf kepercayaan $95 \%$, dengan ketentuan yang berlaku yaitu bila $p$-value $\leq \alpha(0,05)$, maka ada hubungan yang bermakna antara variabel dan variabel dependent. Bila bila p-value $\geq \alpha(0,05)$ maka tidak ada hubungan yang bermakna antara variabel independent dan variabel dependent.

\section{HASIL}

Analisis univariat dilakukan pada tiap variabel penelitian. Pada umumnya dalam analisis ini menghasilkan distribusi dan persentase dari tiap variabel penelitian (Putri; K. Denny, Y. 2014). Berikut akan disajikan analisis univariat dari masingmasing variabel:

Tabel 1. Distribusi Pengawasan pada Pekerja PT JAM Palur

\begin{tabular}{lcccc}
\hline \multirow{2}{*}{ Kepatuhan } & \multicolumn{3}{c}{ Pengawasan } \\
\cline { 2 - 5 } & \multicolumn{2}{c}{ Sebelum } & \multicolumn{2}{c}{ Sesudah } \\
\cline { 2 - 5 } & $\mathrm{f}$ & $\%$ & $\mathrm{f}$ & $\%$ \\
\hline a. Tidak patuh & 68 & 87.2 & 1 & 1.3 \\
b. Patuh & 10 & 12.8 & 77 & 98.7 \\
\hline \multicolumn{1}{c}{ Jumlah } & 78 & 100 & 78 & 100 \\
\hline
\end{tabular}

Berdasarkan hasil penelitian, diketahui bahwa distribusi frekuensi responden yang tidak patuh sebelum pengawasan dalam menggunakan lebih besar, yaitu $87.2 \%$ dibandingkan dengan pekerja yang patuh sebelum pengawasan yaitu $12.8 \%$. Untuk distribusi frekuensi megenai kepatuhan sesudah pengawasan adalah $98.7 \%$ patuh sedangkan yang tidak patuh $1.3 \%$.

Berdasarkan hasil penelitian (tabel $1)$, terdapat 1 orang petugas yang berpengetahuan kurang, tetapi patuh dalam penggunaan APD. Hal ini dikarenakan petugas tersebut pernah mengalami kecelakaan kerja ditempat kerja sebelumnya. Berdasarkan wawancara dengan petugas tersebut, mereka menyatakan tidak nyaman dalam menggunakan APD, APD rusak atau hilang,dan pengawasan yang kurang dari pihak PT. JAM Palur.

Analisis bivariat, analisis ini dilakukan untuk melihat hubungan antara 
variabel independent (pengawasan) dengan variabel dependent (kepatuhan penggunaan APD), melalui uji Paired Samples T Test.

Hasil uji paired samples $t$ test tentang pengaruh pengawasan terhadap kepatuhan penggunaan APD di PT JAM Palur, didapatkan hasil sebagai berikut :

Tabel 2. Paired Samples T Test

\begin{tabular}{lcc}
\hline $\begin{array}{l}\text { Paired Sample T } \\
\text { Test }\end{array}$ & Mean & $\begin{array}{c}\text { Sig. (2- } \\
\text { tailed) }\end{array}$ \\
$\begin{array}{l}\text { Sebelum-sesudah } \\
\text { pengawasan }\end{array}$ & 9,4615 & 0,000 \\
\hline
\end{tabular}

Dari tabel 2 dapat diketahui nilai mean sebesar 9,4615 artinya selisih rata-rata kepatuhan penggunaan APD sebelum dan sesudah pengawasan sebesar 9,4615. Nilai signifikansi (probabilitas) sebesar 0,000 < 0,05 maka H0 ditolak, artinya pengawasan berpengaruh terhadap kepatuhan penggunaan APD (terdapat perbedaan nilai sebelum dan sesudah pengawasan).

\begin{tabular}{l}
\hline \multicolumn{4}{c}{ PEMBAHASAN } \\
\hline Kepatuhan penggunaan APD yaitu \\
perilaku keselamatan spesifik terhadap \\
lingkungan kerja. Kepatuhan penggunaan \\
APD memiliki peran yang penting dalam \\
menciptakan keselamatan di tempat kerja. \\
Dari hasil penelitian di lapangan \\
menunjukkan bahwa kategori kepatuhan \\
penggunaan APD sebelum diadakan \\
intervensi pengawasan paling banyak \\
yaitu pekerja tidak patuh dalam \\
penggunaan APD sebanyak 68 orang \\
(87,2\%). Setelah dilakukan intervensi \\
pengawasan, kategori kepatuhan \\
penggunaan APD pada pekerja paling \\
banyak yaitu total sebanyak 77 orang \\
(98,7\%). Uji yang dilakukan sudah memenuhi \\
syarat, sehingga dapat dilakukan uji paired \\
samples t test. Berdasarkan hasil \\
penelitian diketahui bahwa pengawasan \\
berpengaruh terhadap kepatuhan \\
penggunaan APD di PT JAM Palur. Hasil \\
analisi uji paired samples t test diperoleh \\
nilai signifikansi (probabilitas) sebesar \\
0,000<0,05.
\end{tabular}

Hasil penelitian ini selaras dengan penelitian Joni Siagian (2012) dengan judul Pengaruh Pengawasana dan Kepatuhan terhadap Penggunaan Alat Pelindung Diri pada Perawat dalam Mencegah Infeksi Nosokomial di Rumah Sakit Umum Daerah Kisaran. Hasil penelitian menunjukkan bahwa pengawasan berpengaruh terhadap penggunaan APD dengan nilai probabilitas sebesar 0,060. Selain itu, selaras dengan penelitian yang dilakukan oleh Wibowo (2010) tentang faktor yang berpengaruh terhadap kepatuhan penggunaan APD salah satunya adalah pengawasan. Penelitian terdahulu oleh Bustanul Arifin (2013) menyatakan bahwa sebanyak 53,1 \% pengawasan terhadap kepatuhan penggunaan APD tergolong tidak baik. Adapun hasil uji chi-square didapat $\mathrm{p}$-value sebesar 0,002 sehingga terdapat hubungan antara pengawasan pekerja operator dengan kepatuhan penggunaan APD.

\section{KESIMPULAN}

Berdasarkan uraian di atas dapat ditarik kesimpulan bahwa terdapat pengaruh yang bermakna antara pengawasan terhadap kepatuhan penggunaan APD ( $p$ value $=$ $0.01)$.

\section{UCAPAN TERIMAKASIH}

Kami ucapkan terimakasih kepada PT. Jamu Air Mancur Palur yang sudah membantu dan memfasilitasi kelancaran penelitian ini sehingga bisa selesai tepat waktu.

\section{DAFTAR PUSTAKA}

1. Adikoesoemo, S. 2003. Manajemen Rumah Sakit, Penerbit Pustaka Sinar. Jakarta : Harapan.

2. Arikunto, S. 2006. Prosedur Penelitian Suatu Pendekatan Praktik. Jakarta : Rineka cipta. 
3. Azwar, S. 2006. Penyusunan Skala Psikologi. Yogyakarta : Pustaka Pelajar.

4. Bustanul A, Arif S. 2013. Faktorfaktor yang Berhubungan dengan Kepatuhan Pekerja dalam Pemakaian Alat Pelindung Diri (APD) di Bagian Coal Yard PT X Unit 3 \& 4 Kabupaten Jepara Tahun 2012. Tesis. Semarang : FKM UNDIP.

5. DepKes RI. 2014. 1orang pekerja di dunia meninggal setiap 15 detik karena kecelakaan kerja, dalam http://www.depkes.go.id/article/ 1orang-pekerja-di-dunia-meninggalsetiap-15-detik-karena-kecelakaankerja. Diakses pada tanggal 30 April 2015.

6. Depnakertrans RI. 2004. Pengawasan K3 Lingkungan Kerja, Ditjen
Pembinaan

Pengawasan

Ketenagakerjaan. Jakarta.

7. Effendi, S. 2011. Metode Penelitian Survai. Jakarta : PT Pustaka LP3ES Indonesia.

8. Hair, J. F.; Black, W. C.; Babin, B. J.; Anderson, R. E.; Tatham, R. L. 2006. Multivariate Data Analysis. New Jersey, Upper Saddle River, 6th, Pearson Educational International.

9. Ilham Noviandry. 2013. Faktor-faktor yang Berhubungan dengan Perilaku Pekerja dalam Penggunaan Lat Pelindung Diri (APD) pada Industri Pengelasan Informal di Kelurahan Gondrong, Kecamatan Cipondoh, Kota Tangerang tahun 2013. Skripsi. Jakarta : FKM UIN Syarif Hidayatullah. 